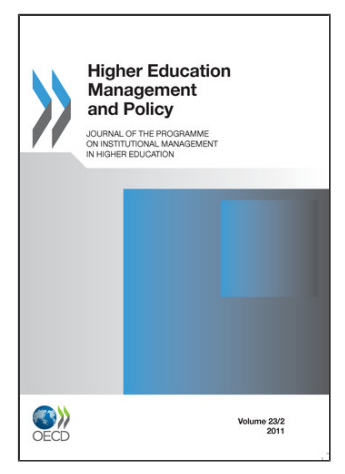

\title{
From: \\ Higher Education Management and Policy
}

Access the journal at:

http://dx.doi.org/10.1787/17269822

\section{New challenges in the governance of Catalan public universities}

Diego Castro, Georgeta Ion

Please cite this article as:

Castro, Diego and Georgeta lon (2011), "New challenges in the governance of Catalan public universities", Higher Education Management and Policy, Vol. 23/2.

http://dx.doi.org/10.1787/hemp-23-5kg8bdpb2qhf 
This document and any map included herein are without prejudice to the status of or sovereignty over any territory, to the delimitation of international frontiers and boundaries and to the name of any territory, city or area. 


\title{
New challenges in the governance of Catalan public universities
}

\author{
by \\ Diego Castro and Georgeta Ion \\ Autonomous University of Barcelona, Spain
}

This article presents the results of a study of the principal issues involved in the governance of public universities in Catalonia. It was based on four stylised dilemmas that were drawn up to facilitate an understanding of the challenges facing university governance reforms. This paper discusses each of these dilemmas in the Catalan context and highlights a number of challenges facing managers of higher education institutions. 


\title{
Les nouveaux défis de la gouvernance des universités publiques catalanes
}

\author{
par \\ Diego Castro et Georgeta Ion \\ Université Autonome de Barcelone, Espagne
}

Cet article présente les résultats d'une étude portant sur les principales questions de la gouvernance des universités publiques en Catalogne. L'étude portait sur l'identification de quatre problèmes dressés pour faciliter la compréhension des défis auxquels les universités doivent faire face suite aux réformes de gouvernance. Cet article examine chaque problème dans le contexte catalan et met en évidence un certain nombre de défis auxquels sont confrontés les gestionnaires des établissements de l'enseignement supérieur. 


\section{Background}

This paper reports the findings of a study undertaken over the last three years by a research team at the Autonomous University of Barcelona. It begins with a discussion of the four dilemmas in the field of university governance identified by Larsen et al. (2009). It then describes governance issues in the Catalan higher education sector, plus the specific dilemmas they face. It details the methodology used for the study as well as its results, based on the fore-mentioned dilemmas. It concludes by highlighting a number of challenges facing managers of higher education institutions in Catalonia.

The recent literature on this subject has revealed tensions in a number of key areas (Sporn, 2003). Lazerson (2010), for example, argues that the necessary changes in university management are controversial on account of the convergence of differing interests, longstanding traditions and different perspectives. More precisely, Larsen et al. (2009) identified four dilemmas in governance, namely those between a) representative democracy and organisational effectiveness; b) integrated management structures and dual management structures; c) external and internal influence in institutional decision-making; and d) between centralisation and decentralisation in more autonomous universities. Our research supports this taxonomy, and we discuss the individual dilemmas in detail below.

The first dilemma arises from the conflict between the dual goals of representative democracy and organisational effectiveness and is a source of tension between the collegiate model and a more professional approach based on results effectiveness. Although university traditions in continental Europe have created generalised management structures that emphasise the role of a representative democracy of academics (Boer and Stensaker, 2007, cited by Larsen et al., 2009), currently the approach geared to results optimisation and efficiency offers a serious alternative. The issue at the heart of the debate is not simply who should manage universities, but also what role and responsibilities should those individuals assume (Demichelle, 2000). One term encountered among the new efficiency-oriented approaches is that of new managerialism. In their study involving heads of department, deans and other senior managers, Deem and Brehony (2005) conclude that the concept and use of new managerialism pervades the way in which unipersonal bodies act, representing a change in the relationships of power and dominance. 
Implementing new managerialism is not simply a technical means to reform the way we approach management; it also implies a change in the way we perceive universities, what they set out to achieve and how they are governed.

The second dilemma arises from the choice between establishing integrated management structures or dual structures. This implies taking decisions about the formal and unambiguous character of roles, styles of leadership and task specialisation. Unlike dual structures, unitary board structures affect the way in which functions and decision making in both academic and administrative areas are organised. A dual structure is characterised by the presence of two hierarchies - academic and administrative - and implies a clear separation between actors and bodies responsible for administrative aspects and teaching staff. This scenario may give rise to conflicts between decision-making bodies.

The third dilemma originates from internal and external influences in decision-making. Universities have frequently been criticised for being out of step with social reality and disconnected from the needs of their environment (Amaral and Magalhães, 2002; European Commission, 2006). In many countries this situation has been accompanied by a tendency to orient reforms towards a model that transfers power to external stakeholders (Henkel, 2005; Jongbloed et al., 2008). This dilemma entails defining the presence of social stakeholders whether to a greater or lesser extent - in university life (Engwall, 2007; Bleiklie and Kogan, 2007); in practice, this manifests itself in the debate that surrounds the composition and competences assumed by every management body. Specifically, this dilemma calls for attention to be paid to the following questions: should senior managers be selected from the business sector or can they be professionals from a different working environment? Should students participate in university governing bodies? If so, should they be considered as internal or external members? These questions widen the debate concerning the size and composition of governing bodies and the need for balanced membership (Woodfield and Kennie, 2007). They also oblige us to consider whether issues such as background should enter into the selection of members (Whitchurch, 2006).

The fourth dilemma stems from the centralisation and decentralisation of universities and relates to the distribution of authority within them (Amaral and Magalhães, 2002). Reforms in recent years have tended to increase the authority of those who have most experience in the field of management and in addressing the challenges this involves. Such moves have generated a certain amount of tension between central and peripheral bodies (Taylor, 2006). A direct consequence of greater university autonomy is that power has been concentrated in the hands of central management bodies, leaving little operational leeway for peripheral units such as faculties and departments (Meister-Scheytt, 2007). This dilemma also raises a number of questions: what 
kind of power should be invested in the different organisational levels and how should this manifest itself? How do quality assurance mechanisms in universities function? What outcomes can be expected? Who determines universities' strategic plans? Clark (1998) and Taylor (2006) have studied these issues, the latter maintaining that one of the major challenges currently facing universities is the need to balance decision making on core issues, with responsibilities geared towards organisational units.

\section{Governance issues in the Catalan higher education sector}

In 1978, the democratic constitution established 20 autonomous regions in Spain; Catalonia is one of them. Since the 1980s the state has increasingly decentralised, devolving power to various autonomous communities in ways which, despite similarities, also show up significant differences. With a population of some seven million people, Catalonia is a region with a long history, a language of its own and distinct traditions, many of which date back to medieval times (Castro and Tomàs, 2011). Today it enjoys considerable autonomy in many areas, including the management of its universities. In practice, this means that although certain general aspects come under state control, the formulation of specific regulations and administrative management of Catalan universities are the responsibility of the regional government, in this case the Generalitat de Catalunya (Catalan Autonomous Government). In 1983, the Spanish central government transferred responsibility for managing universities to the autonomous communities and only retained oversight in a few areas such as determining curricular criteria and issuing degree certificates. In 2003, Catalonia promulgated the Catalan University Law (Llei d'Univeristats de Catalunya), which adapted state regulations to the specificities of the autonomous community.

University governing bodies can be classified on the basis of two variables: composition and scope of influence. The composition of governing bodies can be collegiate or unipersonal; their scope of influence may be general or peripheral (also called territorial). This can be represented in tabular form (Figure 1).

What characterises the unipersonal offices in particular is that they are subject to election and based on principles of representativeness; the style of management is non-professional and they are transient in nature.

A new law concerning university staff is currently pending approval by the Ministry of Education (2010). This law proposes that university administration officers' responsibilities should not impinge on the development of staff in relation to their teaching and research activities. The managerial model of faculties and departments is therefore non-professional. 
Figure 1. Classification of university governing bodies

\begin{tabular}{|c|c|c|c|}
\hline & & \multicolumn{2}{|c|}{ Composition } \\
\hline & & Collegiate & Unipersonal \\
\hline \multirow{2}{*}{ 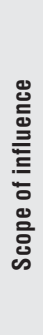 } & 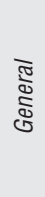 & $\begin{array}{l}\text { - Social Council } \\
\text { - Governing Council } \\
\text { - Senate } \\
\text { - Advisory Body }\end{array}$ & $\begin{array}{l}\text { - Rector } \\
\text { - Vice Chancellor } \\
\text { - Secretary General } \\
\text { - Executive Manager }\end{array}$ \\
\hline & 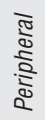 & $\begin{array}{l}\text { - Faculty/School Board } \\
\text { - Department Council }\end{array}$ & $\begin{array}{l}\text { - Dean } \\
\text { - Head of School } \\
\text { - Head of Department }\end{array}$ \\
\hline
\end{tabular}

\section{The context underpinning the dilemmas facing the Catalan higher education system}

The university system in Catalonia clearly belongs to the collegiate model of representative democracy. This means that institutional power is concentrated in the hands of the academic community (Tejerina, 1999; Mora Ruiz, 2000; Michavila and Embid, 2001). This form of management can be termed "professional bureaucracy", as defined by Mintzberg and Quinn (2003). These groups are made up of teachers and students as well as administrative and service staff. In addition, the academic community is composed of several different levels, since teachers are classified by rank and academic status. The outcome of all this is a professional bureaucracy which has the same features as bodies (Middlehurst, 2004). Consequently, managers are elected from among the teachers themselves by members of the academic community, generally the most senior. The result is a non-professional management model. The dean, the head of department and even the rector may all become temporary managing directors, albeit cognisant of the fact that their power depends on the support of the group which elected them.

With regard to the organisational structure of universities, Pedró (2004) has identified that there is a concentration of power around two distinct poles: the academic staff of faculties and departments (academia) on the one hand and administrative and service staff (management) on the other. This has led to the generalisation of permanent-type matrix structures (Mintzberg, 2003). Consequently, from a structural point of view, the academic staff (which includes teachers and researchers) and the management staff (which includes all support, administrative and service personnel) work side by side. In addition to the matrix structures, there is a departmental superstructure which has general oversight over the institution as a whole. 
Another feature of Catalan universities is the low level of external stakeholder involvement in management bodies. From the social point of view, strategic groups are barely represented on management bodies. The only collegiate, external body is the Social Council which oversees certain aspects of university management but essentially economic and budgetary matters.

The Social Council is highly autonomous. It was created to serve as a mechanism to nurture bonding and ensure external control at university level. Its composition is determined by law and includes social partners (unions), employers, municipal officials and representatives of political organisations. For institutions of higher education, the most influential group is the civil service, since universities clearly depend on it from an economic and staffing point of view: almost $60 \%$ of full-time teachers are civil servants. The high number of "teacher officials" has led to an overly rigid structure which is unable to adapt to certain changes and is subject to little pressure from external stakeholders.

Finally, with regard to university autonomy, in a number of areas particularly in the academic area and in terms of curriculum design for graduate and postgraduate degree courses - Catalan universities have increased their scope of action and capacity for decision-making. Nevertheless, autonomy has traditionally been more theoretical than real: since universities are highly dependent on the state, the latter has been obliged to fulfil a considerable number of bureaucratic requirements and to put in place strict administrative control systems. Study fields such as economics, finance and organisation also have very little autonomy. The organisational structure of universities makes a distinction between collegiate and unipersonal bodies, as well as between general (university-wide) and peripheral or territorial bodies (faculties, schools and departments) (Castro and Ion, 2011). Mora Ruiz (2001) maintains that the Spanish system is probably one of the most democratic. The debate is ongoing, however, since it is not only a question of deciding how much decision-making capacity should be given to universities, but also of determining how power should be shared within them. New management systems are currently being tested in which territorial organisations (schools, faculties and departments) take on responsibilities that traditionally have been assumed by general bodies.

In the light of the considerations above, our study aimed to identify the principal dilemmas facing the new governance model of public universities in Catalonia.

\section{Methodology}

The methodology underpinning this study was qualitative in nature and included interviews and focus group discussions. Interviews were conducted with 23 respondents from 4 public universities: Universidad Autónoma de 
Barcelona, Universidad Pompeu Fabra, Universidad Politécnica de Cataluña and Universidad de Barcelona. Three different respondent groups were identified:

- Expert analysts in higher education governance and management. Within this group we conducted seven interviews with European experts in higher education management, as well as external stakeholders and experts working in managerial practice (at the level of chancellor, vice-chancellor and top positions in strategic management).

- Staff in administrative and academic support services. In this group we carried out four interviews with administrative staff representatives.

- Academics performing management functions in departments or faculties. We conducted twelve in-depth interviews with faculty deans and heads of departments, who represent the unipersonal bodies.

The respondent sample was established using non-probability criteria based on their representativeness and Flick's (2004) theoretical sampling. The questions focused on the system of democratic representation, the dysfunctions of matrix structures, the low involvement of critical social groups in university life and the process whereby peripheral units (in particular schools and departments) gain internal autonomy. Subsequently, an interim report was drafted which highlighted the key results obtained from an analysis of the interviews and flagged any that were contradictory. This preliminary report served as a starting point and also oriented the second instrument, a focus group comprised of nine academic experts involved in management issues in higher education institutions.

\section{Results}

The results were organised in line with the concept and structure proposed by Larsen et al. (2009) to be used when addressing the four dilemmas of university management. With regard to the first dilemma, which concerns the potential switch towards a more efficiently organised management model, differing positions were identified among the groups interviewed. The experts argued that the world's most prestigious universities have professional external management systems. Nevertheless, they believe that there is a very strong tradition of academic representation in managerial bodies, and therefore proposed a mixed model in which only the best-qualified or most high-ranking academics would assume management tasks, either in central bodies or faculties and departments.

One possibility is that teachers with significant lecturing and research experience, and who are able speak to others on an equal basis, might assume policy-making positions in universities. At the pinnacle of their professional career, these teachers could specialise in management 
issues with a view to running faculties and university departments. As a trade-off, these teachers would receive recognition and significant compensation, otherwise no high-ranking teacher would sacrifice a career in research and lecturing. [Amparo, expert]

Staff in administrative and support services believed that universities like other major social institutions - should be managed by professionals who do not necessarily need to have an academic background. This group was the least happy with the current model and proposed the most far-reaching reforms. Their grievances included a lack of training available to teachers selected for management responsibilities; the high rotation of academic management positions, which acts as a brake when it comes to developing policies; and a failure among teachers to implement certain measures for fear of becoming unpopular with their colleagues.

If we want to move towards a more professional and competitive university model we should opt for a more professional system. If professionals do things right, they can stay. If not, they can be fired. The problem with academic managers is that they are not totally free to act as they think best. Professionals, however, will take what they consider to be the most appropriate decisions in function of the goals established by their department or faculty. When management is decided by consensus, it is slower and less competitive. [Santiago, manager]

On the other hand, the academics interviewed believed the current model should prevail over any other. They criticised business management models designed for universities and advocated a public university model managed by its academics, controlled, for example, by social accountability mechanisms.

I think the university system is so complex and so unique that only those who really know how it functions are in a position to manage it. This is not the right place for external candidates, since they would not understand how it works. We have codices and a particular language that can only be acquired internally. I don't mean to suggest that we live in an ivory tower, it's simply that we must explain and justify everything we do. [Aída, dean]

Finally, the highest-level academics interviewed stated that university management should remain in the hands of academics although these should benefit from specific training and demonstrate a thorough knowledge of governance.

I think that universities cannot be treated as companies, as their main objective is profit. Continental European universities have a tradition whereby internal democracy and access to managerial positions has been confined to senior academics. Nevertheless, the system is so complex that candidates need previous experience and training in management issues 
as well as clear guidance. Not everyone can be an academic as well as a manager. [Montserrat, vice-chancellor]

In relation to the second dilemma, which resides in the choice between establishing integrated management structures or dual structures, it was noted that the diversification of academic and administrative staff tasks within the university structure was greatly appreciated by both the experts and academics performing management functions who were interviewed. For both of these groups, this diversification permits a differentiation of roles and avoids confusion and conflict between the differing interests of academic and administrative staff. What the experts pointed out, however, is that in Spain, the matrix structure is applied even though it is known that teachers generally take up managerial roles on a temporary basis, which tends to blur the distinction between the two organisational units. This particular state of affairs can potentially generate a number of problems, including a gear shift for academic managers, from an unequivocally political and tactical profile to one which is more operative and entails multiple administrative tasks.

Sometimes we are taken for administrators. Public administration is, on the whole, bureaucratic, since we are required to deal with enormous amounts of paperwork. I am not overly worried about the bureaucracy, but more about the fact that having to deal with so much of it prevents me from doing my own work as a manager and leaves me little time to take decisions and solve specific problems within my faculty. [Nuria, director of a university college]

Furthermore, the academics interviewed regretted that they had little real authority over support and administrative staff.

Even though I am the head of my department, I have no authority over the department secretary. I am probably her manager from a functional, but not an organisational, point of view, since she answers to the faculty manager. I have no say when it comes to important issues. [Ana, head of department]

As a result, the system is dysfunctional - since administrative staff have dual reporting lines. On the one hand, they report to academic managers (organisational dependency); on the other, they report to academics and others who are in a position to give them instructions regarding work content (functional dependency). Administrative and service staff think that this duality should be maintained and that a more unified structure would generate confusion and problems.

I think the [matrix] structure is absolutely vital. Even if the management of teaching and research positions is carried out by teachers, I don't believe they could survive without a strong administrative structure. This doesn't seem to me to be a problem - quite the contrary. [Verónica, school administrator] 
In relation to the third dilemma, the external experts interviewed were open to significant changes to the social groups' current participation model in university management. This, they thought, would make the institution more transparent in the eyes of society.

Social interest groups in other European countries, including individuals from the world of politics, business, culture and science, are more involved in matters affecting the life of the university. In Spain, academics are not keen to see social stakeholders participate in decisionmaking bodies. I think teachers are afraid somebody from outside will try to tell them how to do their job. [Lisa, expert]

It was also evident that there are few systems which allow social stakeholders to be represented and to participate in university life. There were, however, no proposals to increase their representation. Nor did respondents believe that such a situation could create a gap between university and society.

The truth is that when travelling in Europe I see other universities listening more attentively to the business sector, which is how it should be in my opinion. We don't have this tradition in Spain and I can't see the teachers in my department making changes to their courses because of something suggested by a businessman or industrial expert. [José María, head of department]

Regarding the fourth dilemma, which is between centralisation and decentralisation of universities and the distribution of authority within them, respondents agreed that the functions assigned to territorial bodies (schools, faculties and departments) have little relevance to university management and policy making. Although these functions are not subject to restrictions, they are monitored by appropriate collegiate bodies. It was agreed that management bodies responsible for decentralised units should be free to define global guidelines as long as these are in line with the priorities set by university management bodies. From an academic point of view, respondents globally approved of the unipersonal management bodies' autonomy, particularly in relation to the curricula, managing student life and research. Lastly, it transpired that heads of department enjoyed some authority in relation to specific aspects of human resource management, in particular where contracting is concerned.

Respondents reported that internal autonomy is still rather weak. Central bodies are reluctant to decentralise power and hand it over to peripheral organisational units such as departments or faculties. Consequently, the dynamics that are taking place between departments, faculties and university central management are also taking place between universities and government administration. The result is ongoing tension - or a dilemma between the demand for more leeway for decision making and the tendency 
to maintain the current situation. Whatever the case, models that provide greater autonomy and responsibility - counterbalanced by the introduction of accountability systems - are becoming more relevant, if not very widespread.

There is a distinct trend towards homogenisation: the natural tendency for someone in command is to give instructions and enforce rules, in other words, establish homogeneous procedures. This habit is hard to break. But in fact some decisions have been made, and some policies adopted, that attempt to preserve each faculty's individual identity, with its idiosyncrasies, needs and characteristics. Nowadays there tends to be more room for manoeuvre, although homogenising tendencies are still strong and come naturally to people responsible for control and accountability in institutions such as ours. [Rosa, head of department]

\section{Discussion and conclusions}

The study results show that universities are progressively moving towards a traditional collegiate system (Mintzberg, 1984; Vallés, 1996; Luxán, 1998) and are overthrowing the monopoly of power which used to be concentrated in the hands of in-house academics. The management system therefore needs to open up to new formulas such as those of "new managerialism" proposed by Deem and Brehony (2005) or Engwall (2007), who identify a high degree of market management ideology in universities.

The first challenge facing Catalan universities is to turn the current management model into a more professional system specifically oriented towards results effectiveness. In this regard, the academic manager should be seen as a mediator between different interests (Larsen et al., 2009) and be able to develop a dual identity between the traditional ideal of academic governance and the ideal of modern management (Aasen and Stensaker, 2007). The change of approach towards an effectiveness-oriented model should be implemented progressively rather than abruptly. It could begin with the introduction of adjustments to some services or specific areas, before subsequently being rolled out to more generalist areas.

In relation to the second dilemma, our findings concur with those of two other studies. The first is by Pérez and Peiró (1999), who assert that the matrix structure combines departments (as a grouping of teachers devoted to scientific production in one area of knowledge) and schools or faculties (responsible for teaching), while each element of this combination maintains a certain independence. The second study is by Castro and Tomàs (2010), who state that the dual organisational arrangement in universities makes a distinction between academic and managerial staff. It would therefore be accurate to say that Catalan universities are characterised by a double matrix: one is between schools and departments (units) and the other is between 
academic and managerial staff (individuals). This double matrix is, in turn, capped by a department structure that is responsible for general management issues in universities. This means that there is a third organisational axis between the peripheral and general bodies. We can therefore conclude that a university's structure corresponds to three different axes: the rift between schools and departments, between academia and bureaucracy, and between general and peripheral bodies. It is unfeasible to maintain this triple logic in a university structure since it obliges decision making to be dispersed throughout a great number of organisational units, which ultimately dilutes responsibilities among many people. A complex structure such as this, with many levels and lines of decision making, is not efficient. It is a system that effectively dilutes responsibilities and hinders the monitoring of processes and results. A more organic and functional structure could be created by designing organisational units with their own objectives and resources and with autonomy from central bodies.

Results relating to the third dilemma show that when universities enjoy greater autonomy from government administration this does not lead to institutional differentiation, since power is concentrated in general or central bodies. The differentiation and adaptation required in each context should occur through the devolution of power from central bodies (i.e. the university senate) to peripheral units (i.e. faculties and departments). We believe that the management of Catalan universities should fall in line with the trend which is in place in other European countries. There, the participation of internal actors has been considerably reduced, while external stakeholders have become much more active (Stensaker et al., 2007; Santiago et al., 2008; Ferlie et al., 2008).

The Social Council seems to be experiencing difficulty in developing its functions, especially its ability to take decisions related to university guidelines. It also lacks the means to avoid the current conflict between the functions of promotion and control. Lastly, there is still a widespread perception that the composition of the Social Council is dependent on political considerations based on electoral quotas - rather than on social representation. If the Social Council is to become a truly representative body and manage the university community, this situation needs to be reviewed and amended.

Our findings in relation to the fourth dilemma place the Catalan higher education model on a par with systems in other European countries where the management model has been modified in order to increase institutional autonomy (Demichelle, 2000). In this context universities can shape their own management structures, promote institutional decentralisation and integrate social stakeholders into university dynamics. The challenge for university managers, therefore, is to overcome the tendency to centralise decision making within institutions and instead to create a model that can quickly adapt to an increasingly competitive environment, as Larsen et al. (2009) demonstrate in 
reference to Clark (1998). It is urgent to redefine the relationship between university and society, with a view to giving the latter a more representative and relevant role in university life. Those responsible for universities should be held accountable and report on the outcomes and processes generated by their decisions. Social accountability should act as a safety net between university autonomy, the stakeholders and university managers. Ultimately, management reforms should render Catalan universities more permeable to the demands of society, less complex and enable them to fulfil their commitments more effectively.

Despite the findings described above, it is important to underline that our study was subject to some limitations. First, the small number of sample universities (4) and informants (23) limited its representivity, to a certain extent. Second, we examined just one variable of the complex university system: its governance. Consequently, the results of the study should be understood as illustrating governance trends and not as turning points.

The authors:

Diego Castro

Departament de Pedagogia Aplicada, G6/244

08193 Campus Bellaterra

Cerdanyola del Vallès

Spain

E-mail: diego.castro@uab.cat

Georgeta Ion

Departament de Pedagogia Aplicada, G6/248

08193 Campus Bellaterra

Cerdanyola del Vallès

Spain

E-mail: georgeta.ion@uab.cat

\section{References}

Aasen, P. and B. Stensaker (2007), "Balancing Trust and Technology, Leadership Training in Higher Education", International Journal of Educational Management, Vol. 21, pp. 417-433.

Amaral, A. and A. Magelhães (2002), “The Emergent Role of External Stakeholders in European Higher Education Governance", in A. Amaral, G.A. Jones and B. Karseth (eds.), Governing Higher Education: National Perspectives on Institutional Governance, Kluwer Academic Publishers, Dordrecht.

Bleiklie, I. and M. Kogan (2007), “Organization and Governance of Universities”, Higher Education Policy, Vol. 20, Palgrave, pp. 477-493. 
Castro, D. and G. Ion (2011), "Dilemas en el gobierno de las universidades españolas: autonomía, estructura, participación y desconcentración”, Revista de Educación, 355, pp. 161-186.

Castro, D. and M. Tomàs (2010), "El desempeño de la dirección en la universidad", Educación XX1, Vol. 2, pp. 217-239.

Castro, D. and M. Tomàs (2011), "Development of Manager-Academics at Institutions of Higher Education in Catalonia", Higher Education Quarterly, Wiley Blackwell, forthcoming.

Clark, B.R. (1998), Creating Entrepreneurial Universities: Organizational Pathways of Transformation, Pergamon Press, Oxford.

Deem, R. and K. Brehony (2005), "Management as ideology: The Case of 'New Managerialism' in Higher Education”, Oxford Review of Education, Vol. 31, No. 2, pp. 217-235.

Demichelle, F. (2000), "Governance in Higher Education: The Viewpoint of France", Higher Educational Management, Vol. 12, No. 2, pp. 7-16.

Engwall, L. (2007), "Universities, the State and the Market: Changing Patterns of University Governance in Sweden and Beyond", Higher Education Management and Policy, Vol. 19, No. 3, pp. 87-103.

European Commission (2006), Delivering on the Modernisation Agenda for Universities: Education, Research and Innovation, Commission of the European Communities, Brussels.

Ferlie, E., C. Musselin and G. Andresani (2008), "The Steering of Higher Education Systems: A Public Management Perspective”, Higher Education, Vol. 56, pp. 325-348.

Flick, U. (2004), Introducción a la investigación cualitativa, Morata, Madrid.

Henkel, M. (2005), "Academic Identity and Autonomy in a Changing Policy Environment", Higher Education: The International Journal of Higher Education and Educational Planning, Vol. 49, No. 1-2, pp. 155-176.

Jongbloed, B., J. Enders and C. Salerno (2008), "Higher Education and its Communities: Interconnections, Interdependencies and a Research Agenda", Higher Education: The International Journal of Higher Education and Educational Planning, Vol. 56, pp. 303-324.

Larsen, I.M, P. Maassen and B. Stensaker (2009), "Four Basic Dilemmas in University Governance Reform”, Higher Education Management and Policy, Vol. 21/3, pp. 41-58.

Lazerson, M. (2010), Higher Education and the American Dream: Success and its Discontents, Central European University Press, Budapest.

Luxán, J.M. de (ed.) (1998), Política y Reforma Universitaria, Cedecs, Barcelona.

Meister-Scheytt, C. (2007), "Reinventing Governance: The Role of Boards of Governors in the New Austrian University", Tertiary Education and Management, Vol. 13, pp. 247-261.

Michavila, F. and A. Embid (2001), Hacia una nueva universidad, Tecnos, Madrid.

Middlehurst, R. (2004), "Changing Internal Governance: A Discussion of Leadership Roles and Management Structures in UK Universities", Higher Education Quarterly, Vol. 58, No. 4, pp. 258-279.

Ministry of Education of Spain (2010), Estatuto del personal docente e investigador de las universidades españolas, Borrador del decreto, Gobierno de España, Madrid. 
Mintzberg, H. (1979), The Structuring of Organizations: A Synthesis of the Research, Prentice Hall.

Mintzberg, H. and J. Quinn (2003), The Strategy Process, Prentice Hall, US.

Mora Ruiz, J.G. (2000), “El gobierno de las universidades: Entre la autonomía y la eficacia", International Seminar on University Governance and Management, The European Higher Education Society, Barcelona.

Mora Ruiz, J.G. (2001), “Governance and Management in the New University”, Tertiary Education and Management, Vol. 7, pp. 95-110.

Pedró, F. (2004), Fauna académica. La profesión docente en las universidades europeas, UOC, Barcelona.

Pérez, F. and J.M. Peiró (1999), El sistema de gobierno de la universidad española, Secretaria General del Consejo de Universidades, Madrid.

Santiago, P. et al. (2008), Tertiary Education for the Knowledge Society, Vol. 1, OECD Publishing.

Sporn, B. (2003), "Management in Higher Education: Current Trends and Future Perspectives in European Colleges and Universities", in R. Begg (ed.), The Dialogue between Higher Education Research and Practice, Kluwer Academic Publishers, Norwell, US.

Stensaker, B., J. Enders and H.F. de Boer (2007), “Comparative Analysis. Final report of the project: The Extent and Impact of Governance Reform across Europe", http:/ lec.europa.eu/education/pdf/doc236_en.pdf, accessed 8 June 2011.

Taylor, J. (2006), “Big is Beautiful'. Organisational Change in Universities in the United Kingdom: New Models of Institutional Management and the Changing Role of Academic Staff", Higher Education in Europe, Vol. 31, pp. 251-273.

Tejerina, F. (1999), "Alternativas y propuestas de Reforma de los órganos de gobierno de las universidades españolas", in A. Sáenz de Miera (ed.), Sistemas de gobierno de las universidades españolas: situación actual y perspectivas de futuro, Consejo de Universidades, Madrid.

Valles, J.M. (1996), “Gobierno universitario: Entre la autogestión estamental y la responsabilidad social”, Gestión y Análisis de Políticas Públicas, No. 28, pp. 5-6.

Whitchurch, C. (2006), "Who Do They Think They Are? The Changing Identities of Professional Administrators and Managers in UK Higher Education", Journal of Higher Education Policy and Management, Vol. 28, pp. 159-171.

Woodfield, S. and T. Kennie (2007), “Top Team Structures in UK Higher Education Institutions: Composition, Challenges, and Changes", Tertiary Education and Management, Vol. 13, No. 4, pp. 331-348. 